\title{
PERAN MOTIVASI SEBAGAI MEDIATOR ANTARA KESIAPAN BELAJAR DARING DAN PENGALAMAN BELAJAR MAHASISWA DI MASA PANDEMI COVID-19
}

\author{
Ninette Putri Mustika \& Lucia R. M. Royanto
}

Fakultas Psikologi, Universitas Indonesia, Kampus Baru UI Depok, Jawa Barat 16424, Indonesia

Korespondensi: ninette.putri91@ui.ac.id

\section{THE ROLE OF MOTIVATION AS MEDIATOR BETWEEN ONLINE LEARNING READINESS AND UNDERGRADUATE STUDENTS' PERCEIVED LEARNING DURING THE COVID-19 PANDEMIC}

\section{Abstract}

The transition from face-to-face to online learning in this COVID-19 pandemic shapes a unique students' learning experience, including how students perceive their learning experiences, online learning readiness, and academic motivation. This study aims to investigate whether academic motivation mediates the relationship between online learning readiness and perceived learning of university students. The participants comprised undergraduate students who undertook distance learning $(N=381)$. The result showed that academic motivation significantly mediated the relationship between online learning readiness and perceived learning in undergraduate students who conducted distance learning. The result provides references for lecturers, undergraduate students, and universities regarding the importance of having online learning readiness and motivation in order to achieve effective distance learning, especially during this pandemic.
Manuscript type: Original Research

Article history:

Received 7 September 2020

Received in revised form 15 January 2021

Accepted 27 January 2021

Available online 8 April 2021

\section{Keywords:}

academic motivation

distance learning

online learning readiness

perceived learning

\begin{abstract}
Abstrak
Transisi dari pembelajaran tatap muka ke pembelajaran daring di masa pandemi COVID-19 ini membentuk pengalaman belajar yang unik bagi pelajar, termasuk bagaimana pelajar mempersepsikan pengalaman belajar, kesiapan dalam belajar daring, dan motivasi akademik yang dimiliki. Tujuan dari penelitian ini adalah untuk mengetahui hubungan antara kesiapan belajar daring dan pengalaman belajar yang dimediasi oleh motivasi akademik. Partisipan pada penelitian ini adalah mahasiswa sarjana yang sedang melakukan pembelajaran jarak jauh $(N=381)$. Hasil penelitian menunjukkan bahwa motivasi akademik secara signifikan memediasi hubungan antara kesiapan belajar daring dan pengalaman belajar pada mahasiswa yang melakukan pembelajaran jarak jauh. Hasil dari penelitian ini dapat memberikan referensi kepada dosen, mahasiswa, maupun universitas mengenai pentingnya memiliki kesiapan belajar dan motivasi yang tinggi untuk mencapai pembelajaran jarak jauh yang efektif, terutama di masa pandemi ini.
\end{abstract}

Kata Kunci: kesiapan belajar daring, motivasi akademik, pembelajaran jarak jauh, pengalaman belajar

\section{Dampak dan Implikasi dalam Konteks Ulayat}

Pengalaman setiap negara dalam menghadapi pandemi COVID-19 sangat beragam, demikian halnya dengan Indonesia. Hal ini disebabkan oleh banyak faktor, seperti keberagaman kondisi demografi, sosioekonomi, budaya, dan kesiapan sumber daya. Salah satu pengalaman yang disorot dalam penelitian ini adalah pembelajaran jarak jauh dalam konteks perguruan tinggi di Indonesia. Hasil penelitian ini dapat dijadikan acuan untuk penyusunan kebijakan, program intervensi, serta pengembangan kompetensi untuk lembaga pendidikan, mahasiswa, dosen, serta universitas di Indonesia agar dapat meningkatkan kualitas pembelajaran jarak jauh yang berkaitan dengan motivasi akademik, kesiapan belajar daring, dan pengalaman belajar. Selain itu, hasil penelitian ini juga dapat dijadikan pedoman bagi para tenaga pendidik di perguruan tinggi untuk menyusun program intervensi agar mahasiswa mampu menjalani pembelajaran jarak jauh dengan efektif. 


\section{PENDAHULUAN}

Pada bulan Maret 2020, Indonesia dikejutkan dengan berita yang diumumkan langsung oleh Presiden Republik Indonesia (RI), yaitu terdapat dua orang di Indonesia yang dinyatakan positif terinfeksi virus COVID-19 (Nurita, 2020). Virus ini dapat menyerang sistem pernapasan yang menyebabkan seseorang mengalami sesak nafas, bahkan meninggal dunia (World Health Organization [WHO], 2020). Sesuai dengan imbauan dari Presiden RI, beberapa wilayah di Indonesia ikut menetapkan kebijakan untuk menghentikan kegiatan belajar mengajar di sekolah selama setidaknya 2 pekan untuk membatasi kontak langsung dengan orang lain (Kementerian Pendidikan dan Kebudayaan [Kemdikbud], 2020). Menteri Kemdikbud RI, Nadiem Makarim, mengarahkan seluruh pimpinan perguruan tinggi di daerah yang terdampak wabah COVID-19 untuk menghentikan sementara kegiatan akademik secara tatap muka (Kemdikbud, 2020). Hal ini membuat para mahasiswa harus melaksanakan pembelajaran jarak jauh (PJJ).

Pembelajaran jarak jauh (PJJ) merupakan salah satu upaya untuk menyediakan teknik pembelajaran bagi siswa yang jauh secara geografis (Moore dkk., 2011). Dengan semakin berkembangnya teknologi, PJJ saat ini dilakukan secara online atau dalam jaringan (daring). Teknik pembelajaran ini merupakan solusi untuk berbagai masalah pendidikan yang melibatkan tatap muka. Dengan diterapkannya PJJ secara daring, siswa tetap dapat belajar tanpa bertemu secara langsung dengan pengajar (Allen \& Seaman, 2013; Online Learning Task Force, 2011).

PJJ juga diterapkan di Indonesia sejak Kemdikbud RI mengeluarkan Surat Edaran Nomor 4 Tahun 2020 mengenai Pelaksanaan Pendidikan dalam Masa Darurat Penyebaran COVID-19 kepada seluruh pengajar dan mahasiswa untuk melaksanakan PJJ (Menteri Pendidikan dan Kebudayaan Republik Indonesia, 2020). Kondisi ini tentunya menimbulkan berbagai dampak bagi mahasiswa. Penelitian yang dilakukan oleh Amir dkk. (2020) menyatakan bahwa sebanyak 44.2\% mahasiswa di Indonesia lebih memilih untuk melakukan PJJ dibandingkan dengan tatap muka karena mereka tidak perlu berangkat ke kampus untuk menjalani perkuliahan, tetapi partisipan dalam penelitian tersebut harus menghadapi banyak tantangan selama PJJ, seperti koneksi internet yang tidak stabil, kesulitan untuk fokus pada waktu yang lama, serta tidak siap jika harus menjalani PJJ secara utuh tanpa harus berangkat ke kampus (Amir dkk., 2020). Penelitian lain juga menunjukkan bahwa sebanyak 40.5\% mahasiswa di Indonesia tidak siap untuk menjalani PJJ (Giatman dkk., 2020). Hal ini dikarenakan mereka belum pernah melakukan hal ini sebelumnya, minimnya pengetahuan akan media pembelajaran melalui teknologi, serta sinyal internet yang tidak memadai. 
PJJ yang sedang diterapkan saat ini membawa sebuah perubahan besar dalam sistem pendidikan di Indonesia yang biasanya dilakukan dengan tatap muka. PJJ yang dilakukan secara daring membuat pergeseran paradigma sikap terhadap pendidikan pada abad ke-21 (Harasim, 2000). Munculnya pembelajaran daring membuat para pengajar dan siswa perlu memahami dengan baik mengenai kondisi dan sarana untuk mencapai pembelajaran yang efektif (Lee, 2017).

PJJ yang diadakan secara tiba-tiba karena adanya wabah COVID-19 ini membuat seluruh pihak yang terlibat pada institusi pendidikan, baik tenaga pengajar maupun mahasiswa, harus segera beradaptasi dan siap dalam menghadapinya. Di Indonesia, terdapat beberapa universitas yang telah terbiasa untuk menggunakan sistem PJJ lewat media teknologi. Kementrian Riset, Teknologi, dan Perguruan Tinggi Republik Indonesia telah meluncurkan program untuk menunjang e-learning di Indonesia yang dapat diakses oleh seluruh sivitas akademika perguruan tinggi (Fitri, 2018). Layanan ini dapat dimanfaatkan dan sangat membantu pengajar maupun mahasiswa untuk melaksanakan PJJ di masa ini. Yilmaz (2017) menyatakan bahwa pengalaman pembelajaran yang didapatkan oleh mahasiswa tidak hanya bergantung pada layanan pembelajaran yang memadai, tetapi juga apakah mahasiswa tersebut sudah memiliki kesiapan untuk melakukan pembelajaran daring. Oleh karena itu, kesiapan belajar daring tidak hanya meliputi ketersediaan perangkat media teknologi saja, tetapi juga bagaimana secara psikologis para mahasiswa mampu mengikuti pembelajaran dengan baik (Hung dkk., 2010). Beberapa faktor psikologis yang turut memengaruhi kesiapan belajar daring, seperti kemampuan untuk belajar mandiri dan mengatur waktu untuk belajar.

Copriady (2015) menyatakan bahwa motivasi akademik yang dimiliki mahasiswa juga menjadi faktor penting dalam mengikuti PJJ dengan efektif. Jika motivasi akademik yang dimiliki sudah tinggi, maka kecenderungan untuk mempersepsikan pengalaman belajar secara positif semakin meningkat juga (Horzum dkk., 2015), di mana hal ini tidak bergantung pada konteks apakah pembelajaran dilakukan secara tatap muka maupun jarak jauh. Terdapat beberapa faktor penting yang dapat diuji untuk mengetahui efektivitas pelaksanaan PJJ, mulai dari segi cara penyampaian materi, proses pembelajaran, kepuasan siswa, hingga persepsi siswa terhadap pembelajaran yang dialami atau perceived learning (Alqurashi, 2019; Richardson \& Swan, 2003).

\section{Pengalaman Belajar}

Pengalaman belajar (perceived learning) merupakan hal penting pada pencapaian akademik yang dimiliki mahasiswa karena hal ini dapat mengukur apa yang dirasakan oleh mahasiswa 
mengenai pembelajaran yang dialami, serta dapat dikaitkan dengan nilai yang ia dapatkan (Rockinson-Szapkiw dkk., 2016). Karimi dkk. (2013) menyatakan bahwa pengalaman belajar yang dimiliki siswa menjadi faktor yang penting pada keberhasilan pengajar dalam membuat program PJJ. Informasi yang diperoleh mahasiswa atau persepsi mahasiswa mengenai apa yang telah mereka pelajari mungkin saja berbeda dengan hasil yang mereka dapatkan saat ujian (Richardson \& Swan, 2003).

Pengalaman belajar dapat digunakan sebagai tolok ukur dalam melihat pencapaian siswa pada PJJ dibandingkan dengan melihat nilai akhir (Caspi \& Blau, 2011). Caspi dan Blau (2008) mendefinisikan pengalaman belajar sebagai evaluasi retrospektif dari pengalaman belajar yang dialami oleh siswa, yaitu satu set keyakinan dan perasaan yang berkaitan dengan belajar. Pengalaman belajar dapat muncul dari dua sumber, yaitu kognitif dan sosial-emosional (Caspi \& Blau, 2011). Lebih lanjut berkaitan dengan sumber kognitif, dijelaskan bahwa ketika siswa mendapatkan pengetahuan baru, maka siswa tetap dianggap mencapai beberapa pemahaman baru, bahkan jika pengetahuan dan pemahamannya salah (Caspi \& Blau, 2011). Ketika seseorang diminta untuk mengevaluasi pembelajaran mereka, mereka akan menggunakan salah satu sumber. Bloom (1956) mengidentifikasi bahwa pembelajaran terjadi tidak hanya pada ranah kognitif dan afektif saja, tetapi juga dalam ranah psikomotorik. Dengan demikian, pengalaman belajar terdiri dari ketiga aspek tersebut, yaitu: 1) kognitif, saat seseorang menyadari pengetahuan dan kemampuan intelektualnya; 2) afektif, peningkatan sikap positif terhadap materi yang dipelajari; dan 3) psikomotor, mampu mengimplementasikan materi pembelajaran atau pengetahuan yang dimiliki (Rovai dkk., 2009).

Partisipasi aktif dalam diskusi, interaksi dengan dosen, motivasi, kesiapan dalam belajar, serta suasana pada lingkungan pembelajaran daring dapat membuat mahasiswa memiliki pengalaman belajar yang positif (Swan, 2001). Suasana pada lingkungan pembelajaran daring yang dimaksud adalah kesiapan, baik fisik maupun mental. Keadaan pelaksanaan PJJ yang diadakan secara tiba-tiba membuat mahasiswa kewalahan karena beban tugas yang diberikan lebih banyak daripada biasanya, serta membutuhkan penyesuaian diri, sehingga tidak sedikit mahasiswa yang belum siap untuk menghadapinya. Padahal, kualitas interaksi antara mahasiswa dan dosen bergantung pada kesiapan mahasiswa untuk belajar daring (Kaminski dkk., 2009). Pada masa pandemi ini, semua pembelajaran dilakukan secara jarak jauh dengan menggunakan media daring. Hal ini membuat mahasiswa perlu memiliki kesiapan belajar daring yang baik agar kualitas interaksi dan performa pembelajaran yang didapatkan menjadi maksimal (Lai, 2011). Pemanfaatan 
Teknologi Informasi dan Komunikasi (TIK) telah merambah dalam bidang pendidikan sejak diikutsertakan ke dalam kurikulum sesuai dengan Peraturan Menteri Pendidikan Nasional Republik Indonesia Nomor 38 tahun 2008 tentang Pengelolaan Teknologi Informasi dan Komunikasi di Lingkungan Departemen Pendidikan Nasional (Jaringan Dokumentasi dan Informasi Hukum Kemdikbud RI, 2008). Penggunaan media teknologi dalam pembelajaran sehari-hari ini, meliputi penggunaan laptop, e-book, dan media pembelajaran daring lainnya. Namun ternyata, sebanyak $61.5 \%$ mahasiswa di Indonesia belum pernah menggunakan media daring untuk perkuliahan seharihari (Astini, 2020). Oleh karena itu, penting untuk mengetahui kesiapan mahasiswa dalam menggunakan media daring agar dapat menjalani PJJ dengan baik.

\section{Kesiapan Belajar Daring}

Kesiapan belajar daring merupakan suatu perilaku kesiapan siswa yang melibatkan keterampilan teknis dalam menggunakan komputer dan internet, serta kemampuan siswa untuk dapat menemukan preferensi dan strategi yang efektif dalam melakukan pembelajaran daring (Smith, 2005). Kesiapan belajar daring diidentifikasi sebagai prediktor penting dalam pembelajaran yang efektif (Horzum dkk., 2015). Selain itu, kemahiran dalam menggunakan teknologi, khususnya komputer, merupakan faktor penentu dalam keberhasilan komunikasi, interaksi, dan hasil belajar siswa (Yu \& Richardson, 2015). Boeglin dan Campbell (2002) menemukan bahwa kesiapan siswa untuk belajar dan keterampilan mereka menggunakan teknologi untuk menunjang PJJ berdampak positif pada persepsi akan pembelajaran mereka. Hasil ini didukung oleh penelitian lain yang menyatakan bahwa terdapat hubungan positif antara kesiapan belajar daring dan pengalaman belajar (Haverila, 2011).

Tingkat pengalaman belajar siswa yang tinggi dalam pembelajaran daring tidak hanya dipengaruhi oleh kesiapan belajar daring saja, tetapi juga oleh motivasi. Penelitian yang dilakukan oleh Horzum dkk. (2015) menemukan bahwa motivasi akademik memediasi hubungan antara kesiapan belajar daring dan pengalaman belajar. Semakin siap mahasiswa dalam melaksanakan PJJ akan membuat mereka termotivasi untuk dapat menyelesaikan segala tugas yang diberikan (Chen \& Jang, 2010), yang akhirnya akan berdampak pada tingkat pengalaman belajar mahasiswa tersebut. Penelitian yang dilakukan oleh Yilmaz (2017) menyatakan bahwa kesiapan belajar daring menjadi salah satu prediktor munculnya motivasi akademik pada mahasiswa. Motivasi merupakan suatu konsep yang menjelaskan mengapa seseorang bertindak dengan cara tertentu (Schunk, 2007). 


\section{Motivasi Akademik}

Motivasi didefinisikan sebagai suatu proses dimana seseorang menetapkan target dari suatu aktivitas dan mempertahankan target tersebut (Pintrich \& Schunk, 2002). Motivasi akademik merupakan konsep yang lebih spesifik, yaitu melibatkan keterampilan berpikir kreatif dan keterampilan belajar, kepuasan siswa, serta menjadi alasan siswa ingin mengikuti pembelajaran (Philippe \& Vallerand, 2008). Performa yang siswa tunjukkan berkaitan dengan faktor-faktor kognitif, afektif, dan perilaku, sehingga penilaian akan motivasi tidak hanya berdasarkan pada seberapa besar motivasi yang dimiliki, melainkan kualitas dari motivasi itu sendiri (Ryan \& Deci, 2000).

Penelitian yang dilakukan oleh Moore dan Kearsley (2012) terhadap mahasiswa menyimpulkan bahwa motivasi akademik berkaitan dengan pencapaian pada pembelajaran daring. Motivasi akademik yang rendah menjadi salah satu penyebab kegagalan yang dapat mahasiswa rasakan (Bird \& Morgan, 2003). Devoid (2007) menyatakan bahwa motivasi akademik yang dimiliki mahasiswa tidak jauh berbeda dalam melaksanakan PJJ ataupun tatap muka. Jika siswa memiliki motivasi yang tinggi untuk belajar, apapun medianya, siswa tersebut akan mudah untuk mengikuti pembelajarannya. Penelitian lain menunjukkan bahwa tingkat motivasi akademik, khususnya motivasi intrinsik, pada mahasiswa yang melaksanakan PJJ secara signifikan lebih tinggi dibandingkan saat melakukan pembelajaran dengan tatap muka (Rovai dkk., 2007). Dengan kata lain, motivasi akademik penting dimiliki oleh mahasiswa agar dapat berhasil dalam menjalankan pembelajaran daring. Studi yang dilakukan oleh Horzum dkk. (2015) pada siswa yang melakukan Massive Open Online Courses (MOOC) menunjukkan bahwa siswa yang sudah siap untuk belajar daring akan memiliki pengalaman belajar yang tinggi apabila dimediasi oleh motivasi akademik. Hal ini menunjukkan bahwa memiliki kesiapan saja tidak cukup untuk membuat siswa memiliki pengalaman belajar yang baik, tetapi diperlukan juga adanya motivasi yang tinggi dalam mengikuti pelajaran.

Berdasarkan uraian di atas, hipotesis pada penelitian ini adalah motivasi akademik dapat memediasi hubungan antara kesiapan belajar daring dan pengalaman belajar pada mahasiswa. Metode PJJ yang dilaksanakan secara tidak terduga karena pandemi COVID-19 ini menggugah peneliti untuk meneliti lebih lanjut bagaimana mahasiswa mempersepsikan pengalaman belajarnya, serta apakah kesiapan belajar dan motivasi dapat memprediksi hal tersebut. Hasil dari penelitian ini dapat menjadi landasan dalam mengembangkan berbagai program dan kebijakan yang berkaitan 
dengan kesiapan belajar daring dan motivasi akademik agar mahasiswa dapat memiliki pengalaman belajar yang baik, sehingga dapat berhasil menjalani PJJ, khususnya di masa pandemi ini.

\section{METODE}

\section{Partisipan}

Populasi pada penelitian ini adalah mahasiswa sarjana yang sedang menjalankan perkuliahan selama PJJ di 10 Perguruan Tinggi Negeri (PTN) yang termasuk pada klaster satu menurut Kementerian Riset, Teknologi, dan Perguruan Tinggi Republik Indonesia (Kemristekdikti, 2019). Jumlah partisipan yang diperoleh sebanyak 381 mahasiswa. Adapun, jumlah partisipan tersebut didapatkan berdasarkan acuan dari Nunnally (1967) yang menyatakan bahwa sample size yang dibutuhkan untuk menguji model penelitian adalah sebesar 10 kali dari jumlah observed variable. Total observed variable atau butir pada penelitian ini sebanyak 33, sehingga minimal sample size pada penelitian ini adalah 330 partisipan.

Kemristekdikti menilai PTN yang berada pada klaster satu ini dari seberapa aktif perguruan tinggi tersebut merespons perkembangan zaman, terutama revolusi industri keempat yang meliputi perkembangan teknologi untuk pembelajaran, serta kebutuhan tenaga kerja. Kemristekdikti melakukan pengelompokkan PTN ini berdasarkan input (mencakup sumber daya manusia dan mahasiswa), indikator proses (mencakup pengelolaan kampus), indikator output (mencakup pencapaian jangka pendek), dan indikator outcome (mencakup pencapaian jangka panjang) (Kemristekdikti, 2019). PTN yang terdapat pada klaster satu adalah Institut Teknologi Bandung, Universitas Gadjah Mada, Institut Pertanian Bogor, Institut Teknologi Sepuluh Nopember, Universitas Indonesia, Universitas Diponegoro, Universitas Airlangga, Universitas Hasanuddin, Universitas Brawijaya, dan Universitas Padjadjaran. Berdasarkan pengelompokan yang dilakukan oleh Kemristekdikti, alasan peneliti memilih partisipan yang sedang berkuliah di PTN yang termasuk pada klaster satu ini adalah karena PTN tersebut memiliki sistem pembelajaran jarak jauh yang setara, serta telah menggunakan sistem daring sejak sebelum pandemi berlangsung.

Metode pengambilan sampel penelitian yang dilakukan adalah dengan metode accidental sampling, yaitu sampel diperoleh dengan cara memilih individu yang sesuai kriteria yang mudah untuk diperoleh (Kumar, 2011). Metode ini dipilih karena perekrutan partisipan akan dilakukan dengan menyebarkan tautan kuesioner secara daring di berbagai media sosial mengingat keadaan pandemi saat ini mengharuskan seluruh kegiatan dilakukan secara daring. 


\section{Desain}

Penelitian ini merupakan penelitian kuantitatif dengan desain korelasional untuk mengetahui peran motivasi akademik dalam memediasi korelasi antara kesiapan belajar daring dan pengalaman belajar. Penelitian ini telah lolos kaji etik penelitian oleh Komite Etika Penelitian Fakultas Psikologi Universitas Indonesia (Nomor Surat: 803/FPsi.Komite Etik/PDP.04.00/2020).

\section{Prosedur}

Kuesioner disusun secara daring menggunakan Google Form. Metode yang dilakukan untuk menjangkau partisipan yang sesuai dengan kriteria, antara lain: 1) menyebarkan tautan kuesioner dan partisipan dapat mengisi secara sukarela; 2) menghubungi kerabat dengan kriteria yang sesuai untuk menanyakan kesediaan mereka dalam mengisi kuesioner; 3) meminta bantuan kepada berbagai lembaga kemahasiswaan di PTN yang dituju, seperti Badan Eksekutif Mahasiswa atau Himpunan Mahasiswa untuk memohon kesediaan mereka ikut serta menyebarkan tautan kuesioner; serta 4) menaruh tautan kuesioner di media sosial, seperti Twitter dan Instagram agar informasi mengenai tautan kuesioner penelitian ini dapat diketahui oleh banyak orang. Kuesioner tersebut kemudian diisi secara sukarela oleh mahasiswa yang sesuai dengan kriteria yang telah ditentukan.

\section{Instrumen}

Penelitian ini menggunakan tiga alat ukur, yaitu CAP Perceived Learning Scale, Readiness for Online Learning Questionnaire (ROLQ), dan Academic Motivation Scale (AMS) - Short Indonesian Language Version. Sebelum menggunakan ketiga alat ukur tersebut, peneliti telah melakukan korespondensi dengan pemilik alat ukur terlebih dahulu dan sudah mendapatkan izin dalam penggunaan alat ukur tersebut. Ketiga alat ukur ini telah melalui serangkaian proses yang serupa. Dimulai dari adaptasi bahasa ke Bahasa Indonesia, expert judgement (penilaian pakar) dengan tiga dosen dari Program Studi Psikologi Pendidikan di Fakultas Psikologi Universitas Indonesia, uji keterbacaan kepada mahasiswa untuk menguji butir-butir dari kuesioner, serta uji coba alat ukur untuk menguji reliabilitas dan validitas.

Pengalaman belajar didefinisikan sebagai evaluasi dari pengalaman belajar yang dialami oleh mahasiswa. Alat ukur untuk mengukur variabel pengalaman belajar adalah CAP Perceived Learning Scale yang dikembangkan oleh Rovai dkk. (2009). Alat ukur ini dipilih karena mengukur tiga dimensi dari pengalaman belajar, yaitu kognitif, afektif, dan psikomotor yang peneliti gunakan mengacu pada teori learning yang dikemukakan oleh Bloom (1956). Peneliti melakukan adaptasi 
bahasa alat ukur ini ke dalam Bahasa Indonesia melalui proses translasi, expert judgement, serta uji reliabilitas dan validitas. Kemudian, peneliti melakukan modifikasi pilihan jawaban dari tujuh pilihan skala Likert menjadi enam pilihan jawaban. Menurut Sukardi (2011), terdapat kecenderungan pada masyarakat Indonesia untuk memilih kategori jawaban yang berada di tengah karena alasan kemanusiaan. Untuk mengatasi hal ini, peneliti menggunakan skala Likert dengan pilihan genap, yakni enam pilihan. Pilihan jawaban tersebut dimulai dari angka 1 yang mewakili jawaban "Sangat Tidak Menggambarkan Diri Saya" hingga angka 6 yang mewakili jawaban "Sangat Menggambarkan Diri Saya". Alat ukur ini terdiri dari sembilan butir, seperti "Saya dapat mengembangkan kemampuan baru dari apa yang telah saya pelajari". Uji validitas isi dilakukan dengan expert judgement untuk menentukan apakah alat ukur ini valid dalam mengukur pengalaman belajar pada mahasiswa. Hasilnya menyatakan bahwa alat ukur ini layak untuk digunakan. Kemudian, hasil uji reliabilitas juga menunjukkan bahwa alar ukur ini memiliki memiliki konsistensi internal yang baik dengan nilai Cronbach's Alpha sebesar .809. Hasil korelasi butir total menunjukkan nilai yang lebih besar dari .3, artinya butir-butir pada alat ukur ini memiliki korelasi satu sama lain, sehingga memperkuat hasil uji reliabilitas. Setelah melewati proses uji coba alat ukur, total jumlah butir pada alat ukur CAP Perceived Learning Scale adalah sebanyak sembilan butir dengan delapan butir favorable dan satu butir favorable. Berikut terlampir Tabel 1 yang memuat penjelasan lebih lanjut mengenai rincian dari alat ukur ini.

Tabel 1.

Dimensi Alat Ukur CAP Perceived Learning Scale

\begin{tabular}{|c|c|c|c|}
\hline \multirow{2}{*}{ Dimensi } & \multicolumn{2}{|c|}{ Butir } & \multirow{2}{*}{ Contoh Butir } \\
\hline & Favorable & Unfavorable & \\
\hline Kognitif & 1,5 & 2 & $\begin{array}{c}\text { Saya dapat menata materi pembelajaran dalam } \\
\text { struktur yang sistematis. }\end{array}$ \\
\hline Afektif & $4,6,9$ & - & $\begin{array}{l}\text { Setelah mengikuti perkuliahan, sikap saya berubah } \\
\text { terhadap beberapa topik terkait. }\end{array}$ \\
\hline Psikomotor & $3,7,8$ & - & $\begin{array}{l}\text { Saya dapat mengembangkan kemampuan baru dari } \\
\text { apa yang telah saya pelajari. }\end{array}$ \\
\hline
\end{tabular}

Kesiapan belajar daring didefinisikan sebagai kondisi dimana siswa memiliki kepercayaan diri dalam menggunakan media elektronik dan mampu melakukan kegiatan belajar secara mandiri. Alat ukur yang digunakan untuk mengukur kesiapan belajar daring adalah ROLQ yang dikembangkan oleh Smith dkk. (2003). Alat ukur ini digunakan karena sesuai dengan definisi dari kesiapan dalam melakukan PJJ yang telah direncanakan di awal penelitian, serta terdiri dari dua dimensi, yaitu self-management of learning dan comfort with e-learning yang sesuai untuk ditelaah 
lebih lanjut di masa PJJ ini. Dalam mengisi alat ukur, partisipan diminta untuk memilih pilihan jawaban berdasarkan pengalamannya dalam mengikuti PJJ secara daring di masa pandemi ini. Sama seperti alat ukur sebelumnya, ROLQ juga melalui proses adaptasi ke dalam Bahasa Indonesia. Selain itu, modifikasi skala Likert juga dilakukan pada alat ukur ini menjadi enam pilihan jawaban, yaitu angka 1 yang berarti "Sangat Tidak Setuju" hingga angka 6 yang berarti "Sangat Setuju". Setelah dilakukan uji coba alat ukur, terdapat beberapa butir yang dihapus, sehingga alat ukur ini hanya memiliki sebanyak 11 butir saja. Hasil uji validitas isi alat ukur menggunakan metode expert judgement menyatakan bahwa alat ukur ini valid dalam mengukur kesiapan belajar daring pada mahasiswa. Hasil uji reliabilitas juga menunjukkan bahwa ROLQ reliabel dengan nilai Cronbach's Alpha sebesar .704. Hasil koefisien korelasi pada setiap butir menyatakan bahwa semua butir dalam alat ukur ini memiliki konsistensi internal yang baik. Dari 11 butir alat ukur ini, terdapat delapan butir favorable dan tiga butir unfavorable dengan rincian yang dijelaskan pada Tabel 2.

Tabel 2.

Dimensi Alat Ukur Readiness for Online Learning Questionnaire

\begin{tabular}{cccc}
\hline \multirow{2}{*}{ Dimensi } & \multicolumn{2}{c}{ Butir } & \multirow{2}{*}{ Contoh Butir } \\
\cline { 2 - 3 } & Favorable & Unfavorable & Saya adalah individu yang mandiri dalam \\
belajar. \\
$\begin{array}{c}\text { Self-Management of } \\
\text { Learning }\end{array}$ & $4,6,7,11$ & $8,9,10$ & $\begin{array}{c}\text { Saya mudah mengakses internet untuk } \\
\text { pembelajaran. }\end{array}$ \\
\hline
\end{tabular}

Motivasi akademik didefinisikan sebagai proses yang dilakukan siswa dalam menetapkan, mempertahankan, dan mencapai suatu target akademik tertentu. Alat ukur yang digunakan untuk mengukur motivasi akademik pada mahasiswa adalah AMS - Short Indonesian Language Version yang dikembangkan oleh Natalya (2018). Alat ukur ini digunakan karena sesuai dengan definisi motivasi dalam konteks akademik yang mengacu pada pendekatan self-determination theory oleh Ryan dan Deci (2000). Terdapat tiga dimensi motivasi akademik dalam alat ukur ini, yaitu motivasi intrinsik, motivasi ekstrinsik, dan amotivation dengan butir-butir yang mengarah pada motivasi mahasiswa, khususnya dalam bidang akademik. Dimensi motivasi intrinsik terdiri dari tiga komponen, yaitu intrinsic motivation to know, intrinsic motivation to accomplish things, dan intrinsic motivation to experienced stimulation. Dimensi motivasi ekstrinsik juga terdiri dari tiga komponen, yaitu external regulation, introjected regulation, dan identified regulation. Dimensi amotivation merujuk pada ketidakberdayaan yang siswa miliki akan intensi mereka dalam mengikuti berbagai kegiatan akademik. Pilihan jawaban pada alat ukur ini menggunakan skala 
Likert yang terdiri dari enam pilihan jawaban, yaitu angka 1 yang berarti "Sangat Tidak Setuju" hingga angka 6 yang berarti "Sangat Setuju". Peneliti telah melakukan korespondensi kepada Lina Natalya, S.Psi., M.Si. sebagai penulis dalam penelitian pengembangan alat ukur AMS untuk menggunakan alat ukur ini. Hasil uji validitas isi dengan metode expert judgement menyatakan bahwa alat ukur ini layak digunakan untuk mengukur motivasi akademik pada mahasiswa. Hasil uji reliabilitas juga menyatakan bahwa alat ukur ini dapat digunakan untuk mengukur motivasi akademik mahasiswa dengan nilai Cronbach's Alpha sebesar .811. Uji korelasi antar butir juga menyatakan bahwa alat ukur ini memiliki konsistensi internal yang baik dalam mengukur motivasi akademik pada mahasiswa. Tabel 3 di bawah ini berisi penjelasan lebih rinci mengenai dimensi, jumlah butir, serta contoh butir pada alat ukur AMS ini.

Tabel 3.

Dimensi Alat Ukur Academic Motivation Scale (AMS) - Short Indonesian Language Version

\begin{tabular}{|c|c|c|c|}
\hline \multirow{2}{*}{ Dimensi } & \multicolumn{2}{|c|}{ Butir } & \multirow{2}{*}{ Contoh Butir } \\
\hline & Favorable & Unfavorable & \\
\hline Intrinsic Motivation (IM) & & & \\
\hline $\begin{array}{l}\text { Intrinsic Motivation to } \\
\text { Know (IMTK) }\end{array}$ & 1,8 & - & Saya senang belajar hal-hal baru. \\
\hline $\begin{array}{l}\text { Intrinsic Motivation to } \\
\text { Accomplish Things (IMTA) }\end{array}$ & $5,11,14$ & - & $\begin{array}{l}\text { Saya senang ketika berusaha melampaui } \\
\text { target-target pribadi saya. }\end{array}$ \\
\hline $\begin{array}{l}\text { Intrinsic Motivation to } \\
\text { Experienced Stimulation } \\
\text { (IMES) }\end{array}$ & 3,9 & - & $\begin{array}{l}\text { Saya senang terlibat dalam proses diskusi } \\
\text { dengan dosen. }\end{array}$ \\
\hline Extrinsic Motivation (EM) & & & \\
\hline $\begin{array}{l}\text { External Regulation } \\
(\text { EMER) }\end{array}$ & $7,10,12$ & - & $\begin{array}{l}\text { Saya perlu lulus kuliah agar mendapatkan } \\
\text { pekerjaan dengan gaji tinggi. }\end{array}$ \\
\hline $\begin{array}{l}\text { Introjected Regulation } \\
\text { (EMIN) } \\
\text { Identified Reoulation }\end{array}$ & 6,15 & - & $\begin{array}{l}\text { Saya belajar untuk menunjukkan pada diri } \\
\text { sendiri bahwa saya memang pandai. }\end{array}$ \\
\hline $\begin{array}{l}\text { Identified Regulation } \\
(\text { EMID })\end{array}$ & 2 & - & $\begin{array}{l}\text { Dengan berkuliah, memungkinkan saya } \\
\text { mendapatkan pekerjaan yang saya sukai. }\end{array}$ \\
\hline Amotivation (AMOT) & 4,13 & - & $\begin{array}{l}\text { Saya merasa bahwa kuliah hanyalah } \\
\text { membuang-buang waktu. }\end{array}$ \\
\hline
\end{tabular}

\section{Teknik Analisis}

Teknik analisis Pearson Correlation akan dilakukan terlebih dahulu pada penelitian ini untuk mengetahui hubungan antar variabel penelitian. Analisis berikutnya dilanjutkan dengan uji mediasi sederhana dengan menggunakan makro PROCESS V3.4 (Hayes, 2018). Teknik ini digunakan untuk menguji hipotesis penelitian mengenai peran motivasi akademik dalam memediasi hubungan antara kesiapan belajar daring dan pengalaman belajar. 


\section{ANALISIS DAN HASIL}

Dari data yang didapatkan, peneliti mendeskripsikan gambaran demografis, hasil statistik deskriptif, korelasi setiap variabel, serta hasil analisis mediasi sederhana. Di bawah ini terlampir Tabel 4 yang memuat gambaran demografis yang diperoleh dari partisipan penelitian. Berdasarkan tabel tersebut, dapat diketahui bahwa sebagian besar partisipan penelitian merupakan mahasiswa perempuan (74.8\%). Adapun, rentang usia partisipan berkisar dari 18-24 tahun.

Tabel 4.

Gambaran Demografis Partisipan

\begin{tabular}{|c|c|c|c|}
\hline \multicolumn{2}{|c|}{ Karakteristik Partisipan } & $N$ & $\%$ \\
\hline \multirow{2}{*}{ Jenis Kelamin } & Laki-laki & 96 & 25.2 \\
\hline & Perempuan & 285 & 74.8 \\
\hline \multirow[t]{7}{*}{ Usia } & 18 & 23 & 6 \\
\hline & 19 & 110 & 28.9 \\
\hline & 20 & 118 & 31 \\
\hline & 21 & 101 & 26.5 \\
\hline & 22 & 22 & 58 \\
\hline & 23 & 5 & 1.3 \\
\hline & 24 & 2 & .5 \\
\hline \multirow{12}{*}{$\begin{array}{l}\text { Perguruan Tinggi Negeri } \\
\text { Saat Ini }\end{array}$} & Institut Pertanian & 34 & 89 \\
\hline & Bogor & & \\
\hline & $\begin{array}{l}\text { Institut Teknologi } \\
\text { Bandung }\end{array}$ & 43 & 11.3 \\
\hline & Institut Teknologi & & \\
\hline & Sepuluh Nopember & 26 & 6.8 \\
\hline & Universitas Airlangga & 40 & 10.5 \\
\hline & Universitas Brawijaya & 26 & 6.8 \\
\hline & Universitas Diponegoro & 33 & 8.7 \\
\hline & $\begin{array}{l}\text { Universitas Gadjah } \\
\text { Mada }\end{array}$ & 43 & 11.3 \\
\hline & Universitas Hasanuddin & 18 & 4.7 \\
\hline & Universitas Indonesia & 71 & 18.6 \\
\hline & Universitas Padjajaran & 47 & 12.3 \\
\hline \multirow{9}{*}{$\begin{array}{l}\text { Semester yang Sedang } \\
\text { Ditempuh }\end{array}$} & 1 & 1 & .3 \\
\hline & 2 & 95 & 24.9 \\
\hline & 3 & 4 & 1 \\
\hline & 4 & 121 & 31.8 \\
\hline & 5 & 6 & 1.6 \\
\hline & 6 & 111 & 29.1 \\
\hline & 7 & 4 & 1 \\
\hline & 8 & 38 & 10 \\
\hline & 9 & 1 & 3 \\
\hline \multirow{3}{*}{$\begin{array}{l}\text { Regional Tempat Tinggal } \\
\text { Selama PJJ }\end{array}$} & Barat & 355 & 93.2 \\
\hline & Tengah & 23 & 6.0 \\
\hline & Timur & 3 & .8 \\
\hline
\end{tabular}


Partisipan pada penelitian ini sebagian besar merupakan mahasiswa dari Universitas Indonesia (18.6\%), kemudian diikuti dari Universitas Padjadjaran (12.3\%), serta Universitas Gadjah Mada (11.3\%) dan Institut Teknologi Bandung (11.3\%) yang memiliki jumlah yang sama. Mayoritas partisipan sedang menjalani perkuliahan semester empat (31.8\%), kemudian diikuti dengan semester enam (29.1\%) dan semester dua (24.9\%).

Selanjutnya, data demografis partisipan juga menjelaskan mengenai regional tempat tinggal partisipan selama PJJ. Regional ini dibagi menjadi tiga kelompok sesuai dengan zona waktu di Indonesia, yaitu Barat, Tengah, dan Timur. Dapat dilihat bahwa partisipan mayoritas melaksanakan PJJ dari Regional Indonesia Bagian Barat (93.2\%), diikuti dengan Indonesia Bagian Tengah (6.04\%), dan Indonesia Bagian Timur (.8\%).

Peneliti melakukan analisis deskriptif pada setiap variabel penelitian yang terlampir pada Tabel 5. Berdasarkan tabel tersebut, terlihat bahwa partisipan cenderung menilai dirinya sudah memiliki kesiapan belajar daring $(M=3.92 ; S D=.56)$. Partisipan juga menilai bahwa mereka memiliki motivasi akademik dalam melakukan PJJ $(M=4.86 ; S D=.58)$, serta memiliki evaluasi pengalaman belajar yang baik $(M=3.78 ; S D=.85)$.

Tabel 5.

Hasil Pengolahan Statistik Deskriptif

\begin{tabular}{ccccc}
\hline Variabel & Min & Max & Mean & SD \\
\hline Kesiapan Belajar Daring & 2 & 5.27 & 3.92 & .56 \\
Motivasi Akademik & 3.08 & 6 & 4.86 & .58 \\
Pengalaman belajar & 1.33 & 6 & 3.78 & .85 \\
\hline
\end{tabular}

Sebelum melakukan uji hipotesis, peneliti melakukan uji korelasi antar variabel terlebih dahulu. Hasil analisis menunjukkan bahwa terdapat korelasi positif yang signifikan antara kesiapan belajar daring dan motivasi akademik $(r=.44, p<.01)$ yang berarti pengujian mediasi dapat dilakukan. Hasil analisis juga menunjukkan bahwa terdapat korelasi positif yang signifikan antara motivasi akademik dan pengalaman belajar $(r=.46, p<.01)$, serta terdapat korelasi positif yang signifikan antara kesiapan belajar daring dan pengalaman belajar $(r=.56, p<.01)$. Matriks korelasi dapat dilihat pada Tabel 6 . 
Tabel 6.

Matriks Korelasi antar Variabel Penelitian

\begin{tabular}{cccc} 
& $\begin{array}{c}\text { Kesiapan Belajar } \\
\text { Daring }\end{array}$ & Motivasi Akademik & Pengalaman belajar \\
\hline Kesiapan Belajar Daring & - & & \\
Motivasi Akademik & $.44^{* *}$ & - & \\
Pengalaman belajar & $.56^{* *}$ & $.46^{* *}$ & - \\
\hline
\end{tabular}

Catatan: ${ }^{* *}=$ Signifikan pada level .01

Peneliti kemudian melakukan analisis mediasi sederhana untuk menjawab hipotesis penelitian. Hasil analisis mediasi ini menunjukkan bahwa kesiapan belajar daring secara signifikan memprediksi motivasi akademik $(\beta=.5, p<.01)$. Dengan demikian, dapat disimpulkan bahwa sebanyak 19\% varians dari kesiapan belajar daring signifikan dalam menjelaskan motivasi akademik $\left(F(1,379)=93.0358, p<.01, R^{2}=.1971\right)$. Hasil analisis pada jalur b menunjukkan bahwa motivasi akademik secara signifikan memprediksi pengalaman belajar $(\beta=.28, p<.01)$. Peneliti juga menganalisis hubungan antara kesiapan belajar daring terhadap pengalaman belajar dengan melibatkan motivasi akademik dalam perhitungan. Hasil analisis direct effect ini (jalur c') menunjukkan bahwa kesiapan belajar daring secara signifikan dapat memprediksi pengalaman belajar. Dengan demikian, sebanyak 37\% varians dari prediktor signifikan menjelaskan pengalaman belajar $\left(F(2,378)=114.6313, p<.01, R^{2}=.3775\right)$. Rincian lebih lanjut mengenai hasil analisis mediasi sederhana ini dapat dilihat pada Tabel 7.

Tabel 7.

Hasil Analisis Mediasi Sederhana

\begin{tabular}{|c|c|c|c|c|c|c|c|c|}
\hline \multirow[t]{3}{*}{ Antecedent } & \multicolumn{8}{|c|}{ Consequent } \\
\hline & \multicolumn{8}{|c|}{ M (Motivasi Akademik) $\quad$ Y (Pengalaman belajar) } \\
\hline & & Coeff. & $S E$ & $p$ & & Coeff. & $S E$ & $p$ \\
\hline X (Kesiapan Belajar Daring) & a & .5 & .05 & .000 & c' & .55 & .05 & .000 \\
\hline M (Motivasi Akademik) & & - & - & - & b & .28 & .04 & .000 \\
\hline \multirow[t]{3}{*}{ Konstan } & $\mathrm{i}_{\mathrm{M}}$ & 36.83 & 2.26 & .000 & $\mathrm{i}_{Y}$ & -6.43 & 2.82 & .02 \\
\hline & \multicolumn{4}{|c|}{$R^{2}=.1971$} & \multicolumn{4}{|c|}{$R^{2}=.3775$} \\
\hline & & $F(1,37$ & $=93.0$ & $p<.01$ & & $(2,378)$ & 114.6 & $0<.01$ \\
\hline
\end{tabular}


Figur 1 mengilustrasikan uji model dari penelitian ini.

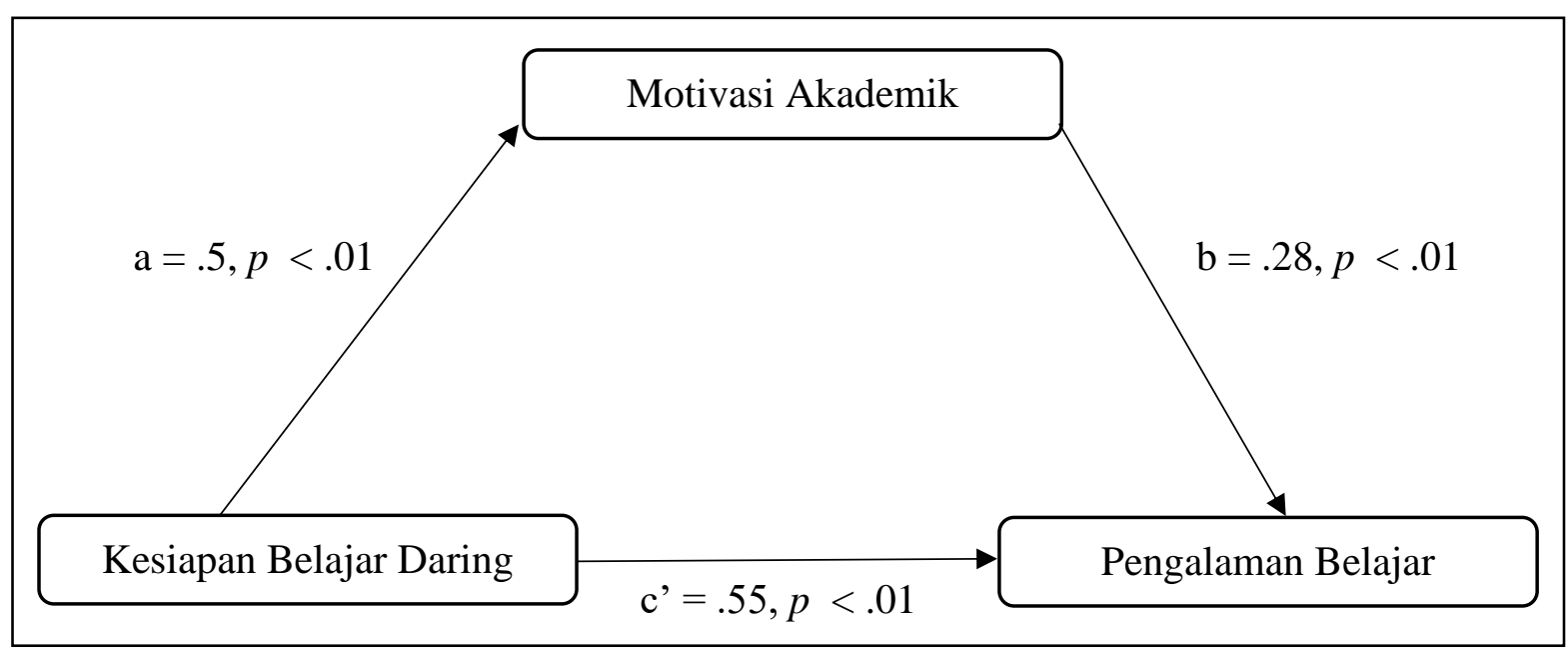

Figur 1. Uji Model Penelitian

Selanjutnya, peneliti menguji peran motivasi akademik sebagai mediator antara hubungan kesiapan belajar daring dan pengalaman belajar. Hasil analisis indirect effect menunjukkan bahwa kesiapan belajar daring signifikan dalam memprediksi pengalaman belajar dengan dimediasi oleh motivasi akademik $(\beta=.1157$, BootSE $=.0230$, BootCI 95\% $[.0705, .1636])$.

\section{DISKUSI}

Hasil analisis data dari penelitian ini menunjukkan bahwa motivasi akademik memediasi hubungan kesiapan belajar daring dan pengalaman belajar. Penelitian ini juga menunjukkan bahwa kesiapan belajar daring dapat memprediksi motivasi akademik secara positif, motivasi akademik dapat memprediksi pengalaman belajar secara positif, serta kesiapan belajar daring memiliki hubungan langsung dengan pengalaman belajar. Hasil temuan pada penelitian ini sejalan dengan penelitian yang dilakukan Horzum dkk. (2015) bahwa motivasi akademik dapat memediasi kesiapan belajar daring dan pengalaman belajar. Hal ini menandakan bahwa meningkatnya kesiapan belajar daring dan motivasi akademik dapat meningkatkan pengalaman belajar yang dimiliki mahasiswa. Seseorang yang memiliki kesiapan belajar daring dan motivasi akademik yang tinggi juga memiliki pencapaian akademik dan hasil belajar yang tinggi (Horzum dkk., 2014).

Berdasarkan data yang didapatkan, terlihat bahwa tingkat kesiapan belajar daring, motivasi akademik, serta pengalaman belajar yang dimiliki oleh mahasiswa sarjana di Indonesia berada di 
atas rata-rata. Hal ini salah satunya dapat terjadi karena partisipan merupakan mahasiswa sarjana dari klaster satu, yakni kelompok perguruan tinggi negeri yang sesuai dengan tingkat perkembangannya, sehingga pada dasarnya memiliki motivasi akademik yang tinggi. Penelitian Choong dkk. (2011) menguatkan hal ini di mana reputasi yang dimiliki oleh institusi pendidikan dan kualitas pengajaran yang diberikan berkaitan dengan motivasi akademik yang dimiliki oleh mahasiswanya. Selain itu, pembelajaran yang dilakukan secara daring juga sudah diterapkan oleh 10 PTN tersebut, sehingga mahasiswa lebih familiar dan siap ketika harus melakukan PJJ pada masa pandemi COVID-19 ini. Mahasiswa yang sudah siap melakukan PJJ akan memiliki motivasi yang tinggi untuk belajar, serta dapat memengaruhi pengalaman belajar yang dimilikinya.

Dalam melaksanakan PJJ, perangkat media elektronik yang digunakan dan jaringan internet menjadi faktor bagi keberhasilan mahasiswa dalam mengikuti pembelajaran. Data demografis pada penelitian ini hanya menjelaskan mengenai provinsi tempat partisipan melaksanakan PJJ, tetapi tidak menggali lebih lanjut mengenai jaringan internet pada daerah tersebut. Dengan demikian, fakta tersebut menjadi keterbatasan dalam penelitian ini. Selain itu, kesiapan belajar daring tidak hanya diukur dari persepsi dan kemampuan mahasiswa dalam menjalani pembelajaran daring, tetapi juga dapat mempertimbangkan hal-hal fisik lainnya, seperti perangkat yang memadai. Oleh karena itu, penelitian selanjutnya diharapkan dapat menganalisis kaitan antara perangkat yang digunakan mahasiswa dengan kesiapannya dalam melakukan pembelajaran daring, serta kecepatan jaringan internet yang dimiliki.

Demir Kaymak dan Horzum (2013) menyatakan bahwa kontrol diri untuk belajar dan selfdirected learning yang dimiliki oleh mahasiswa merupakan komponen penting pada kesiapan belajar daring. Self-directed learning merupakan proses di mana pelajar bertanggung jawab untuk menetapkan tujuan dan mempersiapkan sarana belajar untuk memenuhi tujuan pribadi (Morris, 2019). Kedua komponen ini mampu memprediksi motivasi akademik dan pengalaman belajar pada analisis yang dilakukan. Self-directed learning meliputi rencana belajar, tujuan akademik, dan tanggung jawab yang dimiliki mahasiswa yang berkaitan dengan proses pembelajarannya (Hung dkk., 2010). Motivasi akademik dan pengalaman belajar yang dimiliki mahasiswa dapat menjadi tinggi apabila didukung dengan kesiapan belajar daring di mana self-directed learning dan kontrol diri untuk belajar yang dimiliki juga tinggi. Pada penelitian ini, self-directed learning tidak menjadi variabel yang diteliti. Untuk itu, variabel ini dapat menjadi pertimbangan dalam melakukan studi lanjutan dari penelitian ini. 
Hasil penelitian menunjukkan bahwa kesiapan belajar daring pada mahasiswa dapat memprediksi motivasi akademik yang dimiliki. Semakin tinggi kesiapan mahasiswa untuk melakukan pembelajaran daring, maka motivasi akademiknya juga dapat meningkat. Mahasiswa yang sudah siap untuk melakukan pembelajaran daring dan memiliki kemampuan, serta informasi yang memadai akan memiliki motivasi akademik yang tinggi. Sebaliknya, mahasiswa yang tidak memiliki kesiapan belajar daring akan memilih untuk berhenti dan tidak mendapatkan hasil yang baik (Demir dkk., 2014). Hasil penelitian ini juga sejalan dengan temuan dari Kim dan Frick (2011) bahwa mahasiswa yang mempersepsikan e-learning sebagai metode pembelajaran yang siap ia lakukan akan memiliki motivasi akademik yang tinggi. Hal ini terjadi karena kemandirian dalam belajar sangat dibutuhkan ketika mahasiswa akan melakukan pembelajaran daring, sehingga mahasiswa yang siap akan memiliki keinginan yang tinggi pula untuk dapat menyelesaikan pembelajaran dengan baik hingga selesai.

Hasil analisis data menunjukkan bahwa motivasi akademik memiliki pengaruh terhadap pengalaman belajar pada mahasiswa yang melakukan PJJ. Temuan ini sejalan dengan penelitian yang dilakukan Ferreira dkk. (2011) bahwa semakin tinggi motivasi yang dimiliki seseorang, maka semakin tinggi pula pengalaman belajar yang dimiliki. Hal ini terjadi karena ketika siswa sudah memiliki motivasi yang tinggi untuk melakukan pembelajaran, maka evaluasi akan pengalaman belajarnya juga akan tinggi. Siswa akan cenderung mempersepsikan pengalaman belajarnya adalah hal yang baik ketika ia memiliki keinginan yang tinggi untuk terlibat dalam proses pembelajaran. Vázquez dkk. (2018) juga menyatakan bahwa terdapat hubungan yang positif antara motivasi dan pengalaman belajar pada mahasiswa yang melakukan pembelajaran lewat kelas daring. Mahasiswa yang mampu mengikuti kelas dan menyelesaikannya dengan baik memiliki motivasi akademik yang lebih tinggi dibandingkan dengan mahasiswa yang tidak menyelesaikan kelasnya. Hal ini terjadi karena mahasiswa tersebut merasa mampu untuk menyelesaikan kelas daring dengan sukses (Barak dkk., 2016).

Hytti dkk. (2010) menyatakan bahwa motivasi intrinsik dan ekstrinsik sama-sama memiliki hubungan yang positif terhadap pengalaman belajar yang dimiliki oleh mahasiswa. Namun, Ferreira dkk. (2011) menyatakan bahwa motivasi intrinsik menjadi salah satu faktor yang paling penting dalam memprediksi pengalaman belajar pada mahasiswa. Hasil temuan tersebut juga sejalan dengan penelitian Dalvi-Esfahani dkk. (2020) bahwa pengalaman belajar secara signifikan diprediksi oleh intensi perilaku yang datang dari dalam diri mahasiswa. Pada penelitian ini, motivasi akademik, 
baik intrinsik maupun ekstrinsik, dianalisis secara bersamaan. Hal ini menjadi limitasi dari penelitian yang dapat dikembangkan untuk penelitian selanjutnya.

Temuan lain yang ditemukan pada penelitian ini adalah kesiapan belajar daring memiliki hubungan langsung terhadap pengalaman belajar pada mahasiswa yang melakukan PJJ. Hal ini menunjukkan bahwa mahasiswa yang merasa sudah siap untuk melakukan pembelajaran daring akan memiliki persepsi yang baik terhadap pengalaman pembelajarannya. Penemuan ini sejalan dengan penelitian yang dilakukan oleh Haverila (2011) bahwa kesiapan belajar daring merupakan salah satu faktor yang dapat memprediksi persepsi mahasiswa mengenai efektivitas pembelajaran dan produktivitas pembelajaran. Hal ini terjadi karena salah satu kunci keberhasilan dalam pembelajaran daring adalah mahasiswa memiliki preferensi belajar daring sebagai salah satu cara untuk melakukan proses pembelajaran. Dahalan dkk. (2012) juga menyatakan bahwa siswa yang sudah familiar atau terbiasa untuk menggunakan perangkat teknologi dalam proses belajar akan menunjukkan hasil pembelajaran yang baik pula.

\section{SIMPULAN DAN SARAN}

\section{Simpulan}

Dari penelitian ini, dapat disimpulkan bahwa motivasi akademik mahasiswa sarjana yang sedang melakukan PJJ memediasi hubungan antara kesiapan belajar daring dan pengalaman belajar. Penelitian ini juga menunjukkan bahwa motivasi akademik berperan penting dalam proses pembelajaran mahasiswa. PJJ yang sedang dijalani oleh mahasiswa saat ini membuat kesiapan belajar dan motivasi akademik menjadi penting untuk dimiliki agar mahasiswa dapat memiliki pengalaman belajar yang berada di atas rata-rata, sehingga dapat berhasil menjalani proses belajar di masa pandemi ini.

\section{Saran Teoretis}

Penelitian selanjutnya dapat mengikutsertakan self-directed learning dalam menganalisis pengaruhnya terhadap motivasi akademik dan pengalaman belajar. Kemudian, motivasi akademik dapat dianalisis secara terpisah antara motivasi intrinsik dan ekstrinsik dalam memprediksi pengalaman belajar pada mahasiswa yang melakukan PJJ. Selain itu, penelitian selanjutnya diharapkan dapat menggali lebih dalam mengenai peran dari data demografis, seperti kualitas atau kecepatan jaringan internet, perangkat yang digunakan untuk menunjang keberlangsungan PJJ, serta 
peran gender terhadap kesiapan belajar daring mengingat jumlah partisipan perempuan pada studi ini secara signifikan lebih banyak dibandingkan dengan laki-laki. Ada kemungkinan mahasiswa sudah memiliki kesiapan belajar daring, tetapi karena sinyal internet dan perangkat yang tidak mendukung dapat memengaruhi motivasi akademik, serta pengalaman belajar yang dimiliki.

Kemudian, penelitian ini menggunakan non-probability sampling, yaitu accidental sampling sebagai metode pengambilan sampel. Agar penelitian ini dapat digeneralisasikan untuk seluruh mahasiswa di Indonesia, teknik pengambilan sampel yang dapat dilakukan selanjutnya adalah dengan metode probability sampling. Hal ini dilakukan agar partisipan yang didapatkan lebih heterogen dan hasil penelitian lebih merepresentasikan keadaan mahasiswa sarjana di Indonesia.

\section{Saran Praktis}

Pada penelitian ini ditemukan bahwa motivasi akademik merupakan faktor yang penting pada pengalaman belajar yang dimiliki mahasiswa. Hasil ini dapat menjadi landasan bagi tenaga pendidik untuk merancang program inovasi PJJ agar dapat meningkatkan motivasi mahasiswa. Tenaga pengajar juga dapat memberikan bekal berupa seminar atau pelatihan daring kepada mahasiswa agar memiliki adaptasi yang baik terhadap sistem belajar daring. Selain itu, penelitian ini juga menemukan bahwa kesiapan belajar daring pada mahasiswa memengaruhi pengalaman belajar mahasiswa. Hal ini dapat menjadi pedoman bagi tenaga pengajar maupun institusi pendidikan dalam mendukung mahasiswa untuk memiliki kesiapan belajar daring yang baik. Pedoman tersebut dapat menjadi landasan dalam melatih mahasiswa untuk mahir menggunakan teknologi dalam menunjang pembelajarannya, sehingga memiliki efektivitas yang baik sama halnya ketika kelas tatap muka.

Selain saran yang telah disebutkan di atas, hasil penelitian ini juga dapat meningkatkan kesadaran mahasiswa akan pentingnya kesiapan belajar daring dan motivasi akademik agar dapat memiliki pengalaman belajar yang baik, khususnya di masa COVID-19 ini. Dengan begitu, mahasiswa dapat mulai menyusun kembali rencana pembelajaran, menetapkan tujuan belajar, mempelajari berbagai fitur pada media teknologi yang akan digunakan untuk belajar, dan mengingat kembali motivasi awal untuk menjalani perkuliahan. Hal ini dapat diterapkan agar persepsi akan pengalaman PJJ menjadi baik dan mahasiswa akan lebih efektif menjalankan perkuliahannya. 


\section{REFERENSI}

Allen, I. E., \& Seaman, J. (2013). Changing course: Ten years of tracking online education in the United States. Pearson.

Alqurashi, E. (2019). Predicting student satisfaction and perceived learning within online learning environments. $\quad$ Distance $\quad$ Education, 133-148. https://doi.org/10.1080/01587919.2018.1553562

Amir, L. R., Tanti, I., Maharani, D. A., Wimardhani, Y. S., Julia, V., Sulijaya, B., \& Puspitawati, R. (2020). Student perspective of classroom and distance learning during COVID-19 pandemic in the undergraduate dental study program Universitas Indonesia. BMC Medical Education, 20(1), 1-8. https://doi.org/10.1186/s12909-020-02312-0

Astini, N. K. S. (2020). Tantangan dan peluang pemanfaatan teknologi informasi dalam pembelajaran online masa covid-19. Cetta: Jurnal Ilmu Pendidikan, 3(2), 241-255. http://doi.org/10.37329/cetta.v3i2.452

Barak, M., Watted, A., \& Haick, H. (2016). Motivation to learn in massive open online courses: Examining aspects of language and social engagement. Computers \& Education, 94, 49-60. https://doi.org/10.1016/j.compedu.2015.11.010

Bird, J., \& Morgan, C. (2003). Adults contemplating university study at a distance: Issues, themes and concerns. The International Review of Research in Open and Distributed Learning, 4(1), 1-17. https://doi.org/10.19173/irrodl.v4i1.130

Boeglin, J., \& Campbell, K. (2002). Effects of learners' readiness on their perceived learning outcomes. Canadian Journal of Learning and Technology, 28(2), 1-16. https://doi.org/10.21432/T2CW24

Bloom, B. S. (1956). Taxonomy of educational objectives (Vol 1). David McKay.

Caspi, A., \& Blau, I. (2008). Social presence in online discussion groups: Testing three conceptions and their relations to perceived learning. Social Psychology of Education, 11(3), 323-346. http://doi.org/10.1007/s11218-008-9054-2

Caspi, A., \& Blau, I. (2011). Collaboration and psychological ownership: How does the tension between the two influence perceived learning? Social Psychology of Education, 14(2), 283298. http://doi.org/10.1007/s11218-010-9141-z 
Chen, K. C., \& Jang, S. J. (2010). Motivation in online learning: Testing a model of self determination theory. Computers in Human Behavior, 26(4), 741-752. https://doi.org/10.1016/j.chb.2010.01.011

Choong, Y. O., Lau, T. C., \& Wong, K. L. (2011). Intrinsic motivation and organizational commitment in the Malaysian private higher education institutions: An empirical study. Journal of Arts, Science \& Commerce, 2(4), 91-100.

Copriady, J. (2015). Self-motivation as a mediator for teachers' readiness in applying ICT in teaching and learning. Procedia-Social and Behavioral Sciences, 176, 699-708. https://doi.org/10.1016/j.sbspro.2015.01.529

Dahalan, N., Hassan, H., \& Atan, H. (2012). Student engagement in online learning: Learners attitude toward e-mentoring. Procedia-Social and Behavioral Sciences, 67, 464-475. http://doi.org/10.1016/j.sbspro.2012.11.351

Dalvi-Esfahani, M., Wai Leong, L., Ibrahim, O., \& Nilashi, M. (2020). Explaining students' continuance intention to use mobile web 2.0 learning and their perceived learning: An integrated approach. Journal of Educational Computing Research, 57(8), 1956-2005. http://doi.org/10.1177/0735633118805211

Demir, Ö., Yasar, S., Sert, G., \& Yurdugül, H. (2014). Examination of the relationship between students' attitudes towards computer and self-directed learning with technology. Education and Science, 39(176), 257-266. http://doi.org/10.15390/EB.2014.3621

Demir Kaymak, Z., \& Horzum, M. B. (2013). Relationship between online learning readiness and structure and interaction of online learning students. Educational Sciences: Theory and Practice, 13(3), 1792-1797. http://doi.org/10.12738/estp.2013.3.1580

Devoid, G. H. (2007). The motivations of online learners. (Publication No. 3266264) [Disertasi Doktoral, Capella University]. ProQuest Dissertations and Theses Global.

Ferreira, M., Cardoso, A. P., \& Abrantes, J. L. (2011). Motivation and relationship of the student with the school as factors involved in the perceived learning. Procedia-Social and Behavioral Sciences, 29, 1707-1714. http://doi.org/10.1016/j.sbspro.2011.11.416

Fitri. (2018, April 17). Menristekdikti dan pimpinan 90 ptn, bahas sistem pjj dan online learning. https://lldikti12.ristekdikti.go.id/2018/04/17/menristekdikti-dan-pimpinan-90-ptn-bahassistem-pjj-dan-online-learning.html 
Giatman, M., Siswati, S., \& Basri, I. Y. (2020). Online learning quality control in the pandemic Covid-19 era in Indonesia. Journal of Nonformal Education, 6(2), 168-175. http://dx.doi.org/10.15294/jne.v6i2.25594

Harasim, L. (2000). Shift happens: Online education as a new paradigm in learning. The Internet and Higher Education, 3(1-2), 41-61. https://doi.org/10.1016/S1096-7516(00)00032-4

Haverila, M. (2011). Prior e-learning experience and perceived learning outcomes in an undergraduate e-learning course. MERLOT Journal of Online Learning and Teaching, 7(2), 206-218.

Hayes, A. F. (2018). Introduction to mediation, moderation, and conditional process analysis (2nd ed.). The Guilford Press.

Horzum, M. B., Kaymak, Z. D., \& Gungoren, O. C. (2015). Structural equation modeling towards online learning readiness, academic motivations, and perceived learning. Educational Sciences: Theory \& Practice, 15(3), 759-770. http://doi.org/10.12738/estp.2015.3.2410

Horzum, M. B., Önder, İ., \& Beşoluk, Ş. (2014). Chronotype and academic achievement among online learning students. Learning and Individual Differences, 30, 106-111. https://doi.org/10.1016/j.lindif.2013.10.017

Hung, M. L., Chou, C., Chen, C. H., \& Own, Z. Y. (2010). Learner readiness for online learning: Scale development and student perceptions. Computers \& Education, 55(3), 1080-1090. https://doi.org/10.1016/j.compedu.2010.05.004

Hytti, U., Stenholm, P., Heinonen, J., \& Seikkula-Leino, J. (2010). Perceived learning outcomes in entrepreneurship education. Education + Training, 52(8), 587-606. https://doi.org/10.1108/00400911011088935

Jaringan Dokumentasi dan Informasi Hukum Kemdikbud RI. (2008). Peraturan menteri pendidikan nasional.

https://jdih.kemdikbud.go.id/arsip/Abstraksi\%20Permendiknas\%20Nomor\%20\%2038\%20Ta hun\%202008.pdf

Kaminski, K., Switzer, J., \& Gloeckner, G. (2009). Workforce readiness: A study of university students' fluency with information technology. Computers \& Education, 53(2), 228-233. https://doi.org/10.1016/j.compedu.2009.01.017

Karimi, L., Ahmad, T. \& Badariah T. (2013). Perceived learning and satisfaction in a blended teacher education program: An experience of Malaysian teacher trainees. Contemporary Educational Technology, 4(3), 197-211. https://doi.org/10.30935/cedtech/6103 
Kementerian Pendidikan dan Kebudayaan Republik Indonesia. (2020, Maret 23). Kemdikbud imbau pendidik hadirkan belajar menyenangkan bagi daerah yang terapkan belajar di rumah. https://www.kemdikbud.go.id/main/blog/2020/03/kemendikbud-imbau-pendidik-hadirkanbelajar-menyenangkan-bagi-daerah-yang-terapkan-belajar-di-rumah

Kementerian Riset, Teknologi, dan Pendidikan Tinggi Republik Indonesia. (2019, Agustus 16). Menristekdikti umumkan klasterisasi perguruan tinggi Indonesia 2019, fokuskan hasil dari perguruan tinggi. https://www.ristekbrin.go.id/kabar/menristekdikti-umumkan-klasterisasiperguruan-tinggi-indonesia-2019-fokuskan-hasil-dari-perguruan-tinggi/

Kim, K. J., \& Frick, T. W. (2011). Changes in student motivation during online learning. Journal of Educational Computing Research, 44(1), 1-23. https://doi.org/10.2190/EC.44.1.a

Kumar, R. (2011). Research methodology: A step-by-step guide for beginners (3rd ed.). Sage Publications.

Lai, H. J. (2011). The influence of adult learners' self-directed learning readiness and network literacy on online learning effectiveness: A study of civil servants in Taiwan. Journal of Educational Technology \& Society, 14(2), 98-106. Ditemu kembali Maret 23, 2021, dari https://www.jstor.org/stable/jeductechsoci.14.2.98

Lee, K. (2017). Rethinking the accessibility of online higher education: A historical review. The Internet and Higher Education, 33, 15-23. https://doi.org/10.1016/j.iheduc.2017.01.001

Menteri Pendidikan dan Kebudayaan Republik Indonesia. (2020). Surat edaran nomor 4 tahun 2020 tentang pelaksanaan kebijakan pendidikan dalam masa darurat penyebaran coronavirus disease (COVID-19). https://drive.google.com/file/d/1VrAOA3Qz5bV2p6FgN7Xv7GHVmS0u44Er/view

Moore, J. L., Dickson-Deane, C., \& Galyen, K. (2011). e-Learning, online learning, and distance learning environments: Are they the same? The Internet and Higher Education, 14(2), 129135. https://doi.org/10.1016/j.iheduc.2010.10.001

Moore, M. G. \& Kearsley, I. G. (2012). Distance education: A systems view of online learning (3rd ed.). Wadsworth Publishing Company.

Morris, T. H. (2019). Self-directed learning: A fundamental competence in a rapidly changing world. International Review of Education, 65(4), 633-653. https://doi.org/10.1007/s11159019-09793-2 
Natalya, L. (2018). Validation of academic motivation scale: Short Indonesian language version. Anima Indonesian Psychological Journal, 34-53. https://doi.org/10.24123/aipj.v34i1.2025

Nunnaly, J. C. (1967). Psychometric theory. McGraw-Hill.

Nurita, D. (2020, Maret 2). Jokowi sebut 2 WNI positif virus corona di Indonesia. Tempo. https://nasional.tempo.co/read/1314361/jokowi-sebut-2-wni-positif-virus-corona-di-indonesia

Online Learning Task Force. (2011). Collaborate to compete: Seizing the opportunity of online learning for UK higher education. Higher Education Funding Council for England (HEFCE). http://www.hefce.ac.uk/media/hefce1/pubs/hefce/2011/1101/11_01.pdf

Philippe, F. L., \& Vallerand, R. J. (2008). Actual environments do affect motivation and psychological adjustment: A test of self-determination theory in a natural setting. Motivation and Emotion, 32(2), 81-89. http://doi.org/10.1007/s11031-008-9087-z

Pintrich, P. R., \& Schunk, D. H. (2002). Motivation in education theory, research, and applications (2nd ed.). Prentice Hall.

Richardson, J., \& Swan, K. (2003). Examining social presence in online courses in relation to students' perceived learning and satisfaction. Journal of Asynchronous Learning Network, 7(1), 68-88. http://dx.doi.org/10.24059/olj.v7i1.1864

Rockinson-Szapkiw, A. J., Wendt, J., Whighting, M., \& Nisbet, D. (2016). The predictive relationship among the community of inquiry framework, perceived learning and online, and graduate students' course grades in online synchronous and asynchronous courses. International Review of Research in Open and Distributed Learning, 17(3), 18-35. https://doi.org/10.19173/irrodl.v17i3.2203

Rovai, A., Ponton, M., Wighting, M., \& Baker, J. (2007). A comparative analysis of student motivation in traditional classroom and e-learning courses. International Journal on Elearning, 6(3), 413-432. Ditemu kembali Maret 23, 2021, dari https://www.learntechlib.org/primary/p/20022/

Rovai, A. P., Wighting, M. J., Baker, J. D., \& Grooms, L. D. (2009). Development of an instrument to measure perceived cognitive, affective, and psychomotor learning in traditional and virtual classroom higher education settings. The Internet and Higher Education, 12(1), 7-13. https://doi.org/10.1016/j.iheduc.2008.10.002 
Ryan, R. M., \& Deci, E. L. (2000). Self-determination theory and the facilitation of intrinsic motivation, social development, and well-being. American Psychologist, 55(1), 68-78. http://doi.org/10.1037//0003-066X.55.1.68

Schunk, D. H. (2007). Learning theories: An educational perspective (5th ed.). Prentice Hall.

Smith, P. J. (2005). Learning preferences and readiness for online learning. Educational Psychology, 25(1), 3-12. https://doi.org/10.1080/0144341042000294868

Smith, P. J., Murphy, K. L., \& Mahoney, S. E. (2003). Towards identifying factors underlying readiness for online learning: An exploratory study. Distance Education, 24(1), 57-67. https://doi.org/10.1080/01587910303043

Sukardi. (2011). Metodologi penelitian pendidikan: Kompetensi dan praktiknya. Bumi Aksara.

Swan, K. (2001). Virtual interaction: Design factors affecting student satisfaction and perceived learning in asynchronous online courses. Distance Education, 22(2), 306-331. https://doi.org/10.1080/0158791010220208

Vázquez, J. A. V., Ramirez-Montoya, M. S., \& Gónzalez, J. R. V. (2018). Motivation and knowledge: Pre-assessment and post-assessment of MOOC participants from an energy and sustainability project. The International Review of Research in Open and Distributed Learning, 19(4), 116-132. https://doi.org/10.19173/irrodl.v19i4.3489

World Health Organization. (2020, April 1). Coronavirus disease 2019 (covid-19) situation report. https:/www.who.int/docs/default-source/coronaviruse/situation-reports/20200401-sitrep-72covid-19.pdf?sfvrsn=3dd8971b_2

Yilmaz, R. (2017). Exploring the role of e-learning readiness on student satisfaction and motivation in flipped classroom. Computers in Human Behavior, 70, 251-260. https://doi.org/10.1016/j.chb.2016.12.085

Yu, T., \& Richardson, J. C. (2015). Examining reliability and validity of a Korean version of the community of inquiry instrument using exploratory and confirmatory factor analysis. The Internet and Higher Education, 25, 45-52. https://doi.org/10.1016/j.iheduc.2014.12.004 